\title{
Smile design - based on selected literature with case report
}

\section{Projektowanie uśmiechu - na podstawie wybranego piśmiennictwa z opisem przypadku}

\section{Mayank Kumar Parakh, Krishna Prasad D.}

Department of Prosthodontics and Crown \& Bridge, AB Shetty Memorial Institute of Dental Sciences, NITTE (Deemed to be University), Mangaluru, India

KEY WORDS:

aesthetics, smile, digital design
HASŁA INDEKSOWE:

estetyka, uśmiech, cyfrowe projektowanie

\section{Summary}

Today's modern society gives a lot of precedence to a beautiful and healthy smile and this makes it crucial for dental specialists to make a comprehensive plan to fulfil the patient's desires. An aesthetic smile design can be achieved when dental specialists work hand in hand. Smile designing can revolutionize one's life. Various treatment options exist for restoring a beautiful smile, these include, composite resins, pressable ceramics, CAD/CAM milled prosthesis, Porcelain fused to metal (PFM) crowns, veneers and Lumineers. Patients and dentists both must collaborate and make the final decision so that optimal outcome of treatment can be obtained and patient can gain back the confidence and be more comfortable with their smile. The article describes various aspects in regards to smile designing with in depth explanation of the various components that go along with a beautiful smile. The article also describes a case report of aesthetic smile designing using lithium disilicate veneers using red proportions.

\section{Streszczenie}

Wspótczesne społeczeństwo daje pierwszeństwo pięknemu i zdrowemu uśmiechowi, a to sprawia, że dla stomatologów kluczowe znaczenie ma opracowanie kompleksowego planu spetnienia pragnień pacjenta. Estetyczny projekt uśmiechu można osiagnać, gdy stomatolodzy uwzględniaja obowiązujace zasady. Projektowanie uśmiechu może catkowicie odmienić czyjeś życie. Istnieja różne opcje leczenia $w$ celu przywrócenia pięknego uśmiechu, w tym stosujac żywice kompozytowe, ceramike prasowana, protezy frezowane $C A D / C A M$, korony porcelanowe napalane na metalu (PFM) i licówki. Zarówno pacjenci, jak $i$ dentyści musza wspótpracować i podejmować ostateczna decyzję, aby można byto uzyskać optymalny wynik leczenia, a pacjent mógt odzyskać pewność siebie i czuć się bardziej komfortowo ze swoim uśmiechem. Artykut opisuje różne aspekty zwiazane z projektowaniem uśmiechu $z$ dogłębnym wyjaśnieniem różnych komponentów, które towarzysza pięknemu uśmiechowi. $W$ artykule opisano również opis przypadku estetycznego projektowania uśmiechu przy użyciu licówek z dwukrzemianu litu przy uwzględnienieu zasad białej i czerwonej estetyki. 


\section{Introduction}

A patient's facial expressions form an integral part of non-verbal communication. A smile helps to convey various thoughts and feelings effectively. ${ }^{1}$ Today's modern society gives a lot of precedence to a beautiful and healthy smile, and this makes it crucial for dental specialists to make a comprehensive plan to fulfil the patient's desires. ${ }^{2}$ Undesired spacing, discoloration of teeth, gummy smiles are often considered unesthetic and patients desire a smile design to modify these. ${ }^{3}$

Prior to smile designing, a thorough clinical examination must be carried out. Furthermore, radiographic assessment and diagnostic cast mounting play a crucial role. A complete set of photographs must also be taken so that the patient can be shown the before and after pictures. In order to harmonize an aesthetic, smile, an integration of both the facial and dental components is crucial. The article describes various aspects with regard to smile designing with in depth explanation of the various components that go along with a beautiful smile.

\section{Concepts of smile design-examination of the patient}

Before smile designing is planned, a thorough extra- and intra-oral examination must be performed. During extra-oral examination, the facial and dental midlines, proportions of the face and the facial profile should be assessed. During the intra-oral examination, special consideration should be given to the shape of the dental arch, any defective restorations and the gingival health. ${ }^{4}$ Relevant radiographs such as a full mouth IOPA and OPG must be taken for all cases. If an implant placement is planned, cone beam computed tomography is highly recommended in areas which have anatomic considerations. ${ }^{5}$
Assessment prior to smile designing - general facial analysis

In our day-to-day practice unless a pronounced facial deformity is noted, smile designing is often done only for the dental component. Additionally, the interpupillary line and the lips of the patient play the most important role in the facial features of an individual. Ideally, the interpupillary line must be perpendicular to the plane of occlusion. Lips serve as an important tool for assessing the smile as the smile usually follows the contours of the lip in a case of an aesthetically pleasing smile. ${ }^{6}$

Classically, it has been noted that the face should be the width of five eyes and the facial height can be divided into three vertical sections. The lateral facial profile of the patient can be concave, convex or straight. Furthermore, the shape of the face from the frontal aspect can be square, square tapering, tapering and ovoid. These aforementioned factors play an important role in analyzing the general facial analysis. ${ }^{6,7}$

\section{Dentofacial analysis}

The dentofacial aspect constitutes the hard tissue and the soft tissue components. The hard tissue component encompasses the dental midline, zenith of tooth, width and height of tooth, axial inclination, the sex, personality and age (SPA), interdental contact area and point. The soft tissue components encompass the gingival health, gingival harmony and the interdental embrasure. ${ }^{6}$

\section{Dental midline}

The dental midline is the vertical contact interface between the right and the left maxillary central incisors. Minor discrepancies in facial and dental midline are a common occurrence, and studies have shown that a layperson can identify a deviation of midline greater than $2 \mathrm{~mm}$ when the entire face is viewed, and can identify a deviation of merely $1 \mathrm{~mm}$ when only the lips and teeth are included. ${ }^{8}$ 


\section{Tooth zenith}

The zenith point of the tooth is the most apical point on the cervical tooth margin. The zenith points are different for the maxillary central incisors, lateral incisor and the canine. The zeniths are placed distally from the centre of the tooth in both the incisors while for the canine it falls exactly in the center. Furthermore, the zenith is about $0.74 \mathrm{~mm}$ apicogingivally from the line connecting the zenith of the central incisor and the canine. ${ }^{9}$

\section{Width and height of the tooth}

Dental proportions play an important role in determining the overall aesthetics of the smile. Various ratios have been proposed which include the Golden Proportion, The Recurrent aesthetic dental proportion and the Chu's aesthetic gauge. Various studies have been conducted to assess the prevalence of these proportions in natural dentition, but no study has conclusively found the direct application of one of these proportions to population at large. It can be noted that overall these proportions and gauges can be used as good evaluative tools for aesthetic cases. ${ }^{10-12}$

\section{Incisal edge position}

Maxillary incisal edge position is very important in designing a smile. The incisal edge position is mainly determined by phonetics and aesthetics of an individual. The average display at rest in young individuals is about $2.3 \mathrm{~mm}$ and the display of teeth decreases as the age of the patient increases. ${ }^{13}$

\section{Axial inclination}

Axial inclination of the tooth compares the vertical alignment of the maxillary teeth that are visible in the smile line. Labiolingually, central incisors are placed vertically or slightly buccally while the lateral incisors are also placed buccally but the cervical margin is depressed in relation to the central incisor. On the other hand, the cervical end of the canine is buccally positioned while its tip is more lingually inclined. ${ }^{14}$

\section{Interdental contact area and point}

The interdental contact area is a broad zone in which two teeth touch while the contact point is the most incisal point of the interdental contact area. According to literature, interdental contact area is more important than contact point and this must be used for smile designing. Furthermore, the interdental contact area decreases as we move posteriorly from the central incisor towards the first premolar. ${ }^{15}$

\section{Sex personality and age}

Minor changes in the contour and shape of the anterior teeth can dramatically affect the aesthetics of the patient, and can help in characterizing a patient's smile. In young individuals the incisal edges are not worn out and have high value and low chroma. However, with the increase in age the incisal edges wear down and the chroma of the tooth increases. Females often have more rounded incisal edges in comparison with males. The personality can be influenced significantly by the canine. Aggressive or hostile personalities have sharp canine tips while a more rounded canine appearance indicates a passive personality. 6,16

\section{Soft tissue components - gingival health}

Gingiva in a healthy individual is coral pink with or without pigmentation. The gingival tissue must be completely healthy before starting any aesthetic treatment. Gingiva is usually stippled and firm in a healthy person. Furthermore, studies have noted that the gingiva must be located about $3 \mathrm{~mm}$ coronal to alveolar bone facially and $5 \mathrm{~mm}$ on the interdental aspect. $^{6}$

\section{Gingival level and harmony}

One of the most important goals of smile 
designing is to have a harmony of gingival levels in the maxillary anterior region. The gingival levels of the central incisor and the canine are usually the same while for the lateral incisor it is about $0.5 \mathrm{~mm}$ apicoincisal to the line that connects the aforementioned two teeth. In a recent study it was noted that patients with no gingival display were considered aesthetic by both the dentist and the layperson, while a gingival display of $3 \mathrm{~mm}$ or more was considered highly unaesthetic. ${ }^{17}$

\section{Interdental embrasure}

The display of interdental papilla during smile was noted in over 90 percent of the subjects in studies irrespective of whether the smile had a low or a high line. ${ }^{18}$ We have to bear in mind to avoid black triangles in smile designing which usually appear as a result of the darkness of the oral cavity and lack of interdental papillae in a region. It must also be noted that the contact area should be taken more apically to help avoid a black triangle and achieve pointed and aesthetic interdental papilla. ${ }^{6}$

\section{Smile line}

The smile line is an imaginary line that is formed by connecting the incisal edges of maxillary incisors and cusp tips of the maxillary canine. For a smile to be aesthetic this line should follow the contours of the lower lip. Whenever the incisal edge of the central incisor is shorter than that of the canine tip, the smile takes an inverse curvature and is known as the reverse smile line, and this is often deemed unaesthetic. This reverse smile line must be corrected in order to achieve a harmonious, beautiful and aesthetically pleasing smile. ${ }^{6}$

\section{Prosthetic treatment options for smile designing}

Various treatment options exist for restoring a beautiful smile, and these include composite resins, pressable ceramics, CAD/CAM milled prostheses, porcelain fused to metal (PFM) crowns, veneers and Lumineers.

\section{Digital Smile Designing}

Digital smile designing (DSD) techniques are carried out by means of various digital equipment currently available in dental practices such as a computer with one of the DSD software packages, a digital camera or even a smart phone. ${ }^{29}$ If a complete digital workflow is planned, then an intra-oral scanner, a 3-D printer and $\mathrm{CAD} / \mathrm{CAM}$ software and a milling unit can make the entire workflow digital. ${ }^{30}$ Photographs are very crucial for a digital smile designing and good quality photographs are a must for the patients. Photographs for DSD must be of utmost quality and precision, with correct posture and using facial reference lines like the commissural lines, the lip line and the inter-pupillary line (which forms the basis of smile designing) are established on them. Poor quality photography misrepresents the reference image and may lead to an improper diagnosis and planning. ${ }^{31}$

There are various smile designing software packages that can be used to design a 3-dimensional smile including Photoshop (Adobe System Incorporated), Planmeca Romexis Smile Design (PRSD) (Planmeca Romexis ${ }^{\circledR}$ ), Cerec SW 4.2 (Sirona Dental Systems Inc.), etc. These packages are now quite user friendly and can help design smile digitally. Planmeca Romexis Smile Design, and Cerec SW 4.2 software package can help conduct a 3-D analysis of a smile. ${ }^{32}$ Furthermore, both Planmeca and Cerec can be used to transfer the designed smile data to a CAD/CAM software. ${ }^{32,33}$ The DSD software can enable the users to customize the height and width of each tooth that is part of the smile designing. They can be adjusted to obtain optimal results and this can make it possible for the patient to see his/her smile even before any alterations in the oral cavity have been made. 


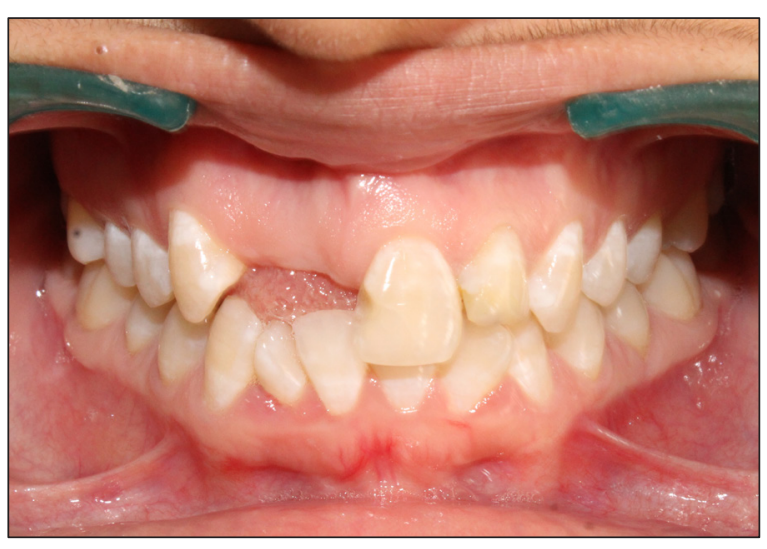

Fig. 1. Patient with missing central and lateral incisor.

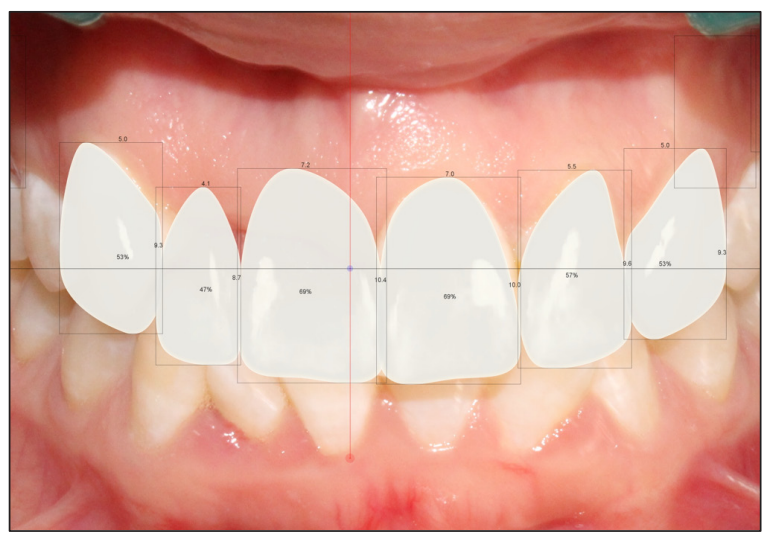

Fig. 3. Smile designing using Planmeca Romexis Smile Design software showing proportion.

Jafri et al. ${ }^{31}$ recommended that full face with the patient at rest, full face with wide smile and a retracted image of the maxillary and mandibular arches be made when viewed in the frontal plane. Furthermore, they recommended an occlusal view of the maxillary arch wherein the teeth from the second premolar on one side to the contralateral second premolar must be covered accurately. They also recommended taking side profiles of the patient in both rest and smile position.

The requirements for photographs vary for different digital smile designing software packages. The Cerec system requires a single image with a wide smile. The programme

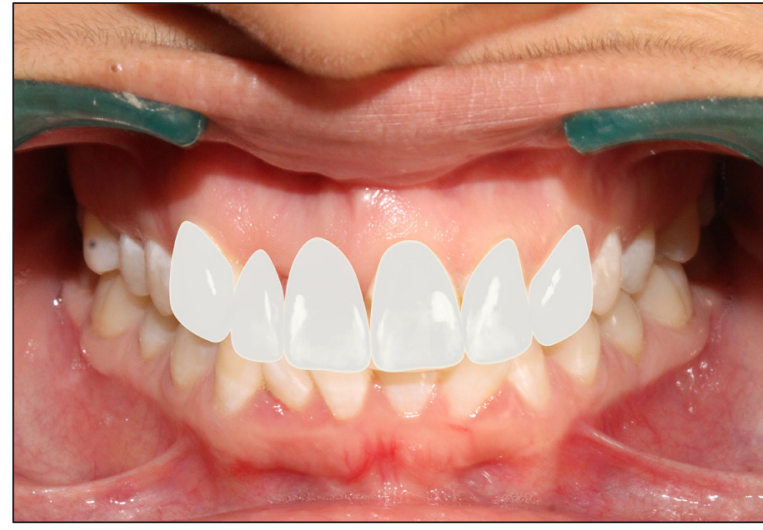

Fig. 2. Planmeca Romexis intelligent tooth silhouette.

uses various facial points to orient the exact positioning of the patient's face. Additionally, it requires an intra-oral scan of the maxillary arch. The designing of the smile then can be done digitally and CAD/CAM milling can be done once optimal aesthetics in the smile designing is obtained. The Planmeca software package requires a minimum of one photograph wherein the patient smiles wide (Fig. 1). In this system first the dimension of the tooth is calibrated. Then the programme has intelligent tooth silhouettes which are placed over the existing teeth and final alterations are made (Fig. 2). Following this, modifications are made to the tooth shape and size according to the desired contours (Fig. 3). The final outcome of the smile design can be visualized following these steps.

Case report - Anterior rehabilitation with all-ceramic veneers

A 21-year-old-patient reported to the department of prosthodontics with the chief complaint of spacing between his upper front teeth which had been present for the past five years (Fig. 4). On further examination it was noted that the premolar in the upper left quadrant had an unaesthetic crown. Various treatment options were explained to the patient 


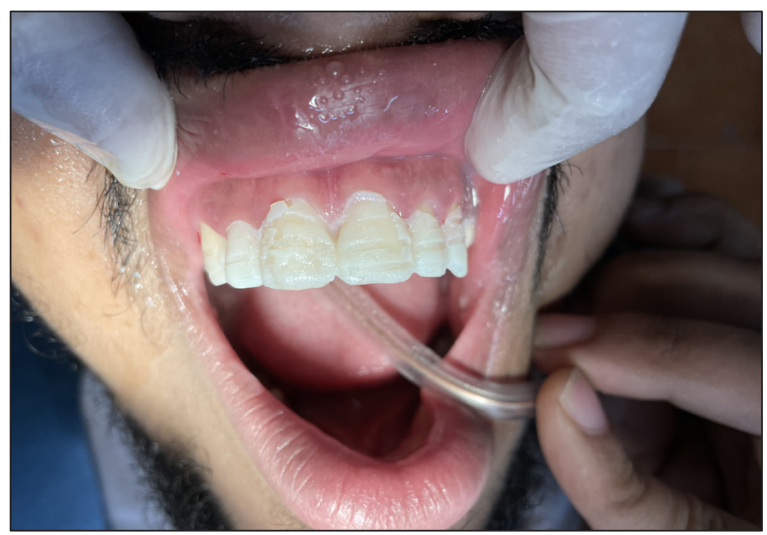

Fig. 4. Preparation throught veneers.

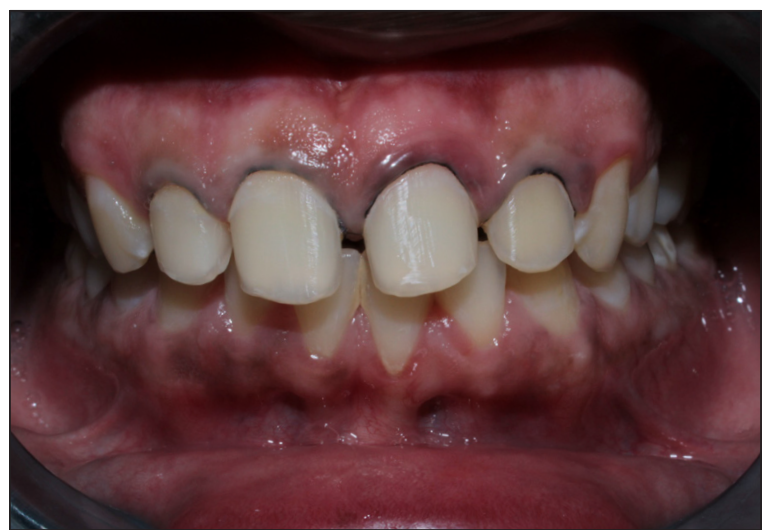

Fig. 6. Final tooth preparation.

who decided to go for lithium disilicate veneers for his anterior teeth. Diagnostic impressions were made, facebow transfer was recorded and an aesthetic mockup was done using golden proportions. The shade was assessed and confirmed with the patient. An aesthetic try-in was done using Protemp 4 (3M ESPE) material and necessary alterations were made. The preparation of the tooth was done to a depth of $0.5 \mathrm{~mm}$ through the aesthetic try-in (Fig. 5). This was done to reduce excessive tooth preparation (Fig. 6). Next, retraction was done using 000 cord and two-stage putty light body impression was made. The cast was poured using type 4 gypsum product (die stone). Accutrac die system was used for sectioning the anterior dies (Fig.

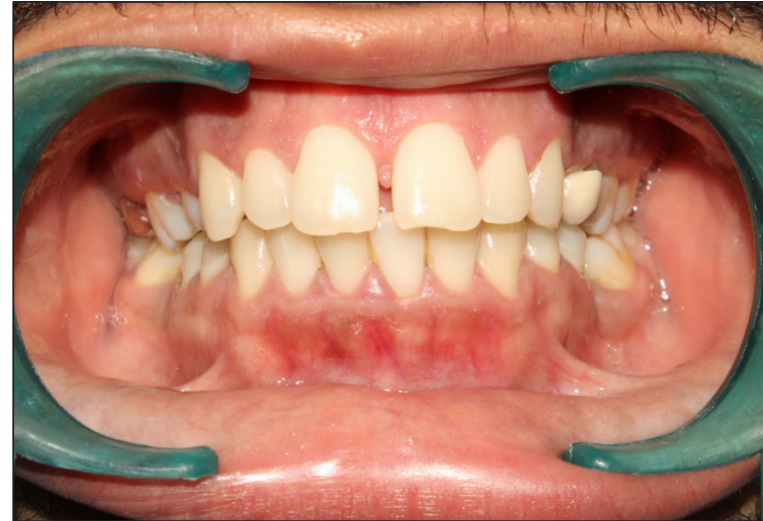

Fig. 5. Pre op.

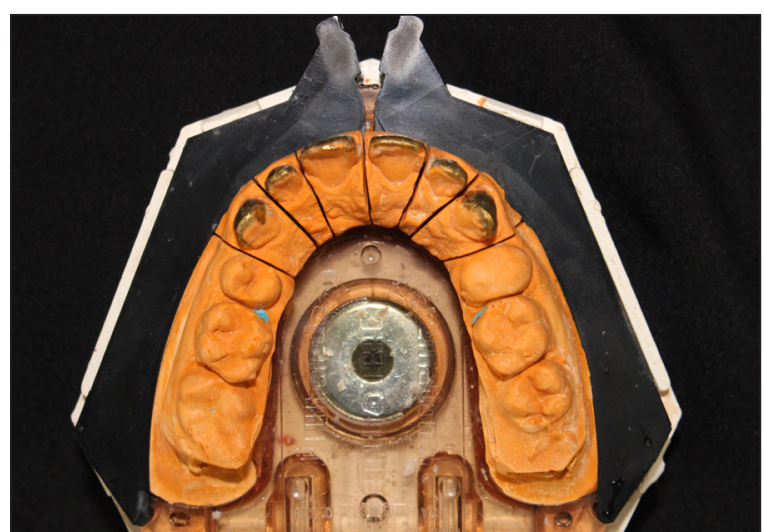

Fig. 7. Accutrac Die system.

7). Subsequently, wax patterns were fabricated and the patterns were invested. Rapid burnout was done and Celtra (Densply Sirona) Medium translucency ingots of A1 shade were used for pressing. The pressing was carried out and the sprues were cut and finishing and polishing of the restoration was done. Teeth were acidetched and copious amount of water was used to remove the etchant. The bonding agent was applied and light-cured for ten seconds. The veneers were luted using Calibra (Densply Sirona) translucent resin cement. Initial tack cure was done and excess cement was removed (Fig. 8, 9). Follow up was performed at three months, six months and one year and no repair or changes were needed. 


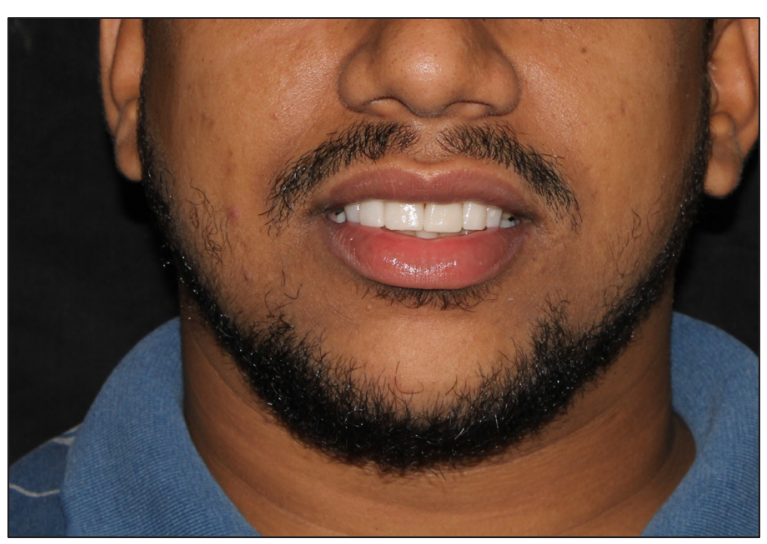

Fig. 8. Final veneers at rest.

\section{Conclusion}

Smile designing - a smile makeover must be done with a systematic approach and maintaining the principles of smile designing. Additionally, the smile that the dentist creates must be both aesthetically and functionally sound. The patient can gain confidence and often perform better at their work with a more confident smile. With proper planning, excellent aesthetic results can be achieved. Both patients and dentists must collaborate and make the final decision so that optimal outcome of treatment can be obtained, the patient can regain the confidence and be more comfortable with their smile.

\section{References}

1. Silva CHV: Dentes claros - sorriso transformador - qual o papel do cirurgião dentista. Odontol Clín-Sci 2011; 10: 115-115.

2. Kakehashi Reges $R V$, et al.: Proporção áurea: um guia do tratamento estético. JBD - Jornal Brasileiro de Dentística e Estética, Curitiba 2002; 1: 292-295.

3. Silva LCD, Silva RFD, Higashi DT, Pfau VJM, Pfau EA: Correction of smile through multidisciplinary approach. J Surg Clin Dent 2016; 9: 5-11.

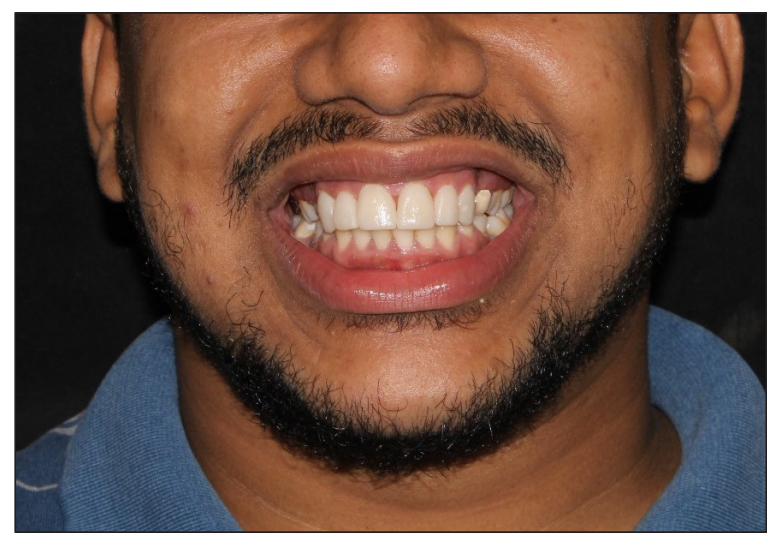

Fig. 9. Smile of the patient.

4. MiroA, Shalman A, MoralesR, Giannuzzi NJ: Esthetic Smile Design Limited Orthodontic Therapy to Position Teeth for Minimally Invasive Veneer Preparation. Dent Clin N Am 2015; 59: 675-687.

5. Jacobs $R$, Salmon B, Codari M, Hassan $B$, Bornstein MM: Cone beam computed tomography in implant dentistry: recommendations for clinical use. BMC Oral Health 2018; 18: 88.

6. Bhuvaneswaran $M$ : Principles of smile design. J Conserv Dent 2010; 13(4): 225-232. doi:10.4103/0972-0707.73387

7. Bukhary SM, Gill DS, Tredwin CJ, Moles DR: The influence of varying maxillary lateral incisor dimensions on perceived esthetic smile. Br Dent J 2007; 203: 687-693.

8. Ferreira JB, Silva LE, Caetano MT, Motta AF, Cury-Saramago AA, Mucha JN: Perception of midline deviations in smile esthetics by laypersons. Dental Press J Orthod 2016; 21(6): 51-57.

9. Shah DH, Takodara DM, Bhatia DY, Mehta $D S$ : Gingival Zenith - A Critical Factor in Smile Design and Fixed Prosthodontics: Gingival Zenith - A Critical Factor in Smile Design and Fixed Prosthodontics. Natl J Integr Res Med 2018; 7, 113-116.

10. Ward DH: Proportional Smile Design. Dent Clinics North Am 2015; 59(3): 623-638. 
11. Wagh SA, Mantri SS, Bhasin A: Evaluation of maxillary anterior teeth proportion with Chu's Gauge in a population of Central India: an in vivo study. Med Pharm Rep 2020; 93(1): $75-$ 80. doi:10.15386/mpr-1309

12.ldegheishem A, Azam A, Al-Madi E, AbuKhalaf L, Bani Ali B, Anweigi L: Golden proportion evaluation in maxillary anterior teeth amongst Saudi population in Riyadh. Saudi Dent J 2019; 31(3): 322-329.

13. AlRafee MA, AlRafee AS, Alanzan AS, AlRafie HS, AlGhureibi AS, AlMujibah MR, et al.: Anterior teeth visibility and its relation to aging among saudi population. Ann Dent Spec 2020; 8: 79-85.

14. Moore T, Southard KA, Casko JS, Qian $F$, Southard TE: Buccal corridor and Smile esthtetics. Am J Orthod Dentofacial Orthop 2005; 127: 208-213.

15. Kolte AP, Kolte RA, Bawankar P: Proximal contact areas of maxillary anterior teeth and their influence on interdental papilla. Saudi Dent J 2018; 30: 324-329.

16. Chiche GJ, Pinault A: Smile Rejuvenation. A methodic approach. Pract Periodontics Aesthet Dent 1993; 5: 37-44.

17. Maniyar M, Kalia A, Mirdehghan N, Nene S, Bhagwagar P: Evaluation of the influence of gingival display on smile esthetics in Indian females-a computer-aided photographic analysis. J Indian Orthod Soc 2018; 52: 100105.

18. Albarrak AA, AlRumaih HS, Al-Humaidan A, Al-Thobity AM, Alshahrani FA: Multi disciplinary approach with predictable esthetics: A case report. Saudi Dent J 2019; 31: S89-S95.

19. Bhuvaneswaran $M$. Principles of smile design. J Conserv Dent 2010; 13: 225-232.

20. Espindola-Castro LP, Monteiro GQM, Ortigoza LS, SilvaCHV, Souto-Maior $J R$ : Multidisciplinary Approach to Smile Restoration: Gingivoplasty, Tooth Bleaching, and Dental Re-anatomization. Compendium
2019; 40: 1-5.

21. Cattoni F, Mastrangelo F, Gherlone EF, Gastaldi G: A New Total Digital Smile Planning Technique (3D-DSP) to Fabricate CAD-CAM Mockups for Esthetic Crowns and Veneers. Int J Dent 2016; 1-5.

22. Deliberador TM, Weiss SG, Neto ATD, Zetola IZ, Prix MES, Júnior DR, et al.: Guided Periodontal Surgery: Association of Digital Workflow and Piezosurgery for the Correction of a Gummy Smile. Case Reports in Dentistry. 2020; 1-6.

23. Kühl S, Zürcher S, Mahid T, Müller-Gerbl M, Filippi A, Cattin P: Accuracy of full guided vs. half-guided implant surgery. Clin Oral Implants Res 2013; 24: 763-769.

24. Priya Mukherjee: "Peak into the Future with Digital Smile Designing (DSD)". Acta Scientific Dental Sciences 2019; 3: 67-73.

25. Coachman C, Dooren EV, Gürel G, Landsberg CJ, Calamita MA, Bichacho N: "Smile design: from digital treatment planning to clinical reality". In: Cohen M (ed). Interdisciplinary treatment Planning". Comprehensive Case Studies. Chicago, IL: Quintessence 2. 2012.

26. Brown JD, Monetti L: The midline crisis: esthetically. Gen Dent 1987; 35: 110-111.

27. Singh S, Jasoria G, Kushwah A, Soni S: Macroesthetic Elements of Smile; A Review Article TMU J Dent 2018; 5: 23-26.

28. Morley J: Smile design. Course presented at: Advanced Esthetics Continuum, Louisiana Academy of Continuing Dental Education, Louisiana State University School of Dentistry, 2000; New Orleans.

29. Daher R, Ardu S, Vjero O, Krejci I: 3D digital smile design with a mobile phone and intraoral optical scanner. Comp Cont Educ Dent 2018; 39(6): e5-8.

30. Aragón ML, Pontes L, Bichara L, Flores-Mir $C$, Normando $D$ : Validity and reliability of intraoral scanners compared to conventional gypsum models measurements: a systematic review. Eur J Orthod 2016; 38: 429-434. 
31. Jafri Z, Ahmad N, Sawai M, Sultan N, Bhardwaj A: Digital Smile Design-An innovative tool in aesthetic dentistry. J Oral Biol Craniofac Res 2020; 10(2): 194-198.

32. Paolucci B, Calamita M, Coachman C, Gurel $G$, Shayder A, Hallawell P: Quintessence of Dental Technology; 2012. Visagism: The Art of Dental Composition; pp. 1-14.

33. https://online.planmeca.com/store/
SmileDesign.action, Assessed on 15th

October, 2021.

Zaakceptowano do druku: 19.11.2021 r.

Adres autorów: Department of Prosthodontics and Crown\&Bridge, Mangalore, India e-mail: drkrishnaprasadd@nitte.edu.in (c) Zarząd Główny PTS 2021. 